\title{
Social Determinants of Health and their influence on the choice of birth control methods
}

\author{
Determinantes Sociais da Saúde e sua influência na escolha do método contraceptivo \\ Determinantes Sociales de la Salud y su influencia en la elección del método anticonceptivo
}

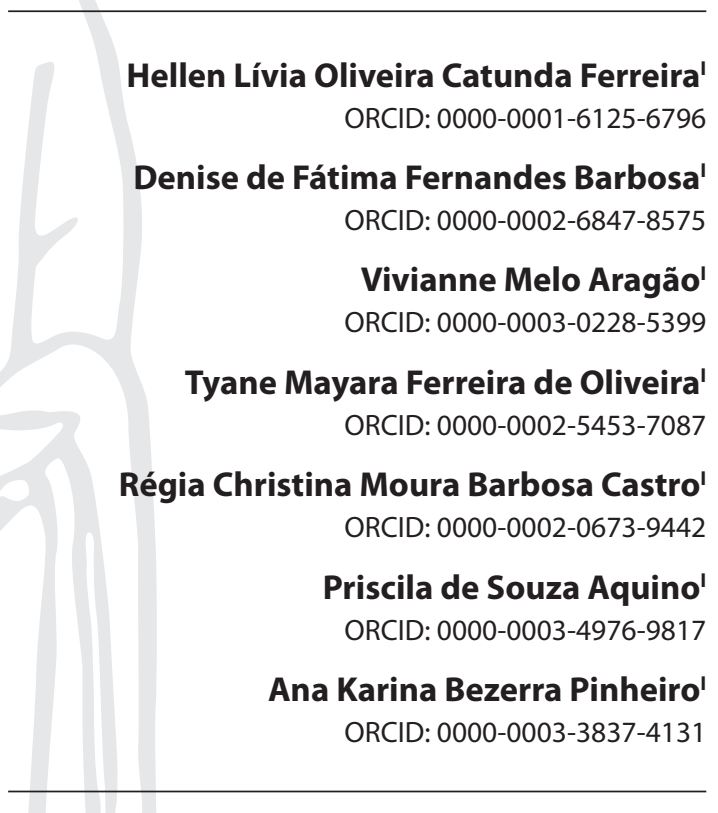

'Universidade Federal do Ceará. Fortaleza, Ceará, Brazil.

How to cite this article:

Ferreira HLOC, Barbosa DFF, Aragão VM, Oliveira TMF, Castro RCMB, Aquino PS, Pinheiro AKB. Social Determinants of Health and their influence on the choice of birth control methods. Rev Bras Enferm. 2019;72(4):1044-51. doi: http://dx.doi.org/10.1590/0034-7167-2017-0574

Corresponding Author: Hellen Lívia Oliveira Catunda Ferreira E-mail: hellen_enfermagem@yahoo.com.br

Submission: 08-10-2017

Approval: 02-23-2018

\section{ABSTRACT}

Objective: To verify the association between Social Determinants of Health and birth control methods used by women of childbearing age. Methods: Documentary and retrospective study, performed at a Brazilian Natural Birth Center with evaluation of the medical records of patients seen between 2003 and 2011 ( $n=2410)$. Data were collected on identification and general history, gynecological, sexual and obstetric. Results: Hormone birth control methods were the most used among participants (25.0\%); followed by barrier methods (21.5\%) and surgical methods (19.3\%). Statistical associations were observed regarding age, menarche, onset of sexual activity, pregnancy, miscarriage, smoking, hypertension, marital status, gynecological care and schooling with the choice of methods. Conclusion: The results confirm the importance of studies involving Social Determinants of Health, since they interfere in the way women choose birth control methods and the risks that this choice may pose to their health.

Descriptors: Women's Health; Contraception; Nursing; Social Determinants of Health; Public Health.

\section{RESUMO}

Objetivo: Verificar a associação entre os Determinantes Sociais da Saúde e o método contraceptivo utilizado por mulheres em idade fértil. Métodos: Estudo documental e retrospectivo, realizado em um Centro de Parto Natural com avaliação dos prontuários de pacientes atendidas entre 2003 e 2011 ( $n=2410$ ). Foram coletados dados de identificação e histórico geral, ginecológico, sexual e obstétrico. Resultados: Destacaram-se os métodos hormonais como os mais utilizados entre as participantes da pesquisa $(25,0 \%)$, seguido pelos métodos de barreira (21,5\%) e pelos métodos cirúrgicos (19,3\%). Foram observadas associações estatísticas acerca da idade, menarca, início da vida sexual, gravidez, aborto, tabagismo, hipertensão, estado civil, cuidado ginecológico e escolaridade com a escolha dos métodos. Conclusão: Os resultados ratificam a importância de estudos envolvendo os Determinantes Sociais da Saúde, visto que interferem na forma como as mulheres escolhem os métodos contraceptivos e os riscos que essa escolha pode representar para a sua saúde. Descritores: Saúde da Mulher; Anticoncepção; Enfermagem; Determinantes Sociais da Saúde; Saúde Pública.

\section{RESUMEN}

Objetivo: Verificar la asociación entre los Determinantes Sociales de la Salud y el método anticonceptivo utilizado por mujeres en edad fértil. Métodos: Estudio documental y retrospectivo, realizado en un Centro de Parto Natural con evaluación de los prontuarios de pacientes atendidos entre 2003 y 2011 ( $n=2410)$. Se recogieron datos de identificación e histórico general, ginecológico, sexual y obstétrico. Resultados: Se destacaron los métodos hormonales como los más utilizados entre las participantes de la investigación $(25,0 \%)$, seguido por los métodos de barrera $(21,5 \%)$ y por los métodos quirúrgicos $(19,3 \%)$. Se observaron asociaciones estadísticas sobre edad, menarquia, inicio de la vida sexual, embarazo, aborto, tabaquismo, hipertensión, estado civil, cuidado ginecológico y escolaridad con la elección de los métodos. Conclusión: Los resultados ratifican la importancia de estudios que involucran a los Determinantes Sociales de la Salud, Determinantes Sociales de la Salud que interfieren en la forma en que las mujeres escogen los métodos anticonceptivos y los riesgos que esa elección puede suponer para su salud. Descriptores: Salud de la Mujer; Anticoncepción; Enfermería; Determinantes Sociales de la Salud; Salud Pública. 


\section{INTRODUCTION}

Reproductive planning contributes to a healthier sexual practice and constitutes a right, having to consider the individual life context and the decisions of each one according to their needs.

In Brazil, until 1984, there was no public policy instituted in this field, and it was included in the minimum list of actions aimed at comprehensive care to women's health, up to the preparation of the Programa de Assistência Integral à Saúde da Mulher (PAISM, freely translated as Program for Comprehensive Care to Women's Health). The Federal Constitution regulated family planning and, in 1996, the management bodies of the Brazilian Unified Health System (SUS - Sistema Único de Saúde), at all levels, became obliged to assure conception and contraception as a matter of respect for sexual rights and reproductive ${ }^{(1)}$.

Attention to contraception presupposes the provision of information, counseling, clinical follow-up and a range of scientifically accepted anti-conception methods and techniques that do not endanger life and health. It is important to offer different contraceptive options for all stages of reproductive life so that individuals have the possibility to choose the method most appropriate to their needs and life circumstances ${ }^{(1)}$.

In the last 10 years, according to the National Survey of Demography and Health of Children and Women (PNDS), carried out in 2006, which outlines a profile of the childbearing age female population, it was verified that the women are initiating the activity Sexuality, as well as the practice of contraception. It is a fact that most women of childbearing age and sexually active have already used some contraceptive method, being the male condom and the pill the most cited methods ${ }^{(2)}$.

In order for this choice to be free and informed, it is necessary to maintain the supply of contraceptive methods in the public health network and to have professionals trained to help the couple to make their contraceptive option at any time in their lives. However, there are innumerable factors influencing this choice and adherence to contraceptive methods, such as socioeconomic and cultural aspects ${ }^{(3)}$.

Social conditions have always influenced health, but the concept of social determinants emerged in the late 1970s and early 1980s. It is generally about the living and working conditions of individuals and groups of the population that are related to their health situation ${ }^{(4)}$.

Social Determinants of Health (SDH), according to the model of Dahlgren and Whitehead (2007), are arranged in concentric layers in which individuals are at the center of the model, namely: Layer 1 (individual determinants: age, sex, genetic inheritance); Layer 2 (proximal determinants: individual behaviors and lifestyles); Layer 3 (influence of social networks); Layer 4 (intermediate determinants: living conditions, work, food, access to essential environments and services, such as health, education, sanitation, housing); Layer 5 (distal or macrodeterminant determinants: economic, cultural and environmental conditions of society, including supranational determinants such as globalization) $)^{(5)}$.

Thus, this study aims to understand which social determinants interfere in the choice of birth control method and contribute positively to the assistance to women in reproductive planning.

\section{OBJECTIVE}

This study aims to verify the association between Social Determinants of Health and birth control methods used by childbearing age women.

\section{METHOD}

\section{Ethical aspects}

The project was submitted to the Research Ethics Committee of the Universidade Federal do Ceará (UFC) and the ethical principles for research with human beings present in Resolution 466/12 of the National Health Council (Conselho Nacional de Saúde) of Brazil ${ }^{(6)}$ were respected. The board of directors of the Lígia Barros Costa Natural Birth Center (NBC) was also requested to carry out the study by means of medical records.

\section{Design, place of study and period}

A cross-sectional, retrospective study with a quantitative approach, developed at the Lígia Barros Costa NBC, a specific Nursing care place linked to the UFC Extension Pro-Rectory, which provides care to women in the area of Sexual and Reproductive Health.

\section{Population, sample, criteria of inclusion and exclusion}

The study population consisted of women attending the unit, in the field of Gynecological Nursing appointment, from the beginning of its operation, from October 2003 to December 2011. A total of 3357 medical records were identified. The inclusion criteria were: to have at least one appointment at the institution to perform the Pap test; and have an active sex life. The exclusion criteria were: not to have started sexual activity; not having performed the Pap test; and charts with insufficient information to analyze the study. 2410 medical records were selected as final sample.

\section{Study protocol}

The data were collected from the eligible medical records from March to September 2013, using a structured form composed of identification variables, general history, gynecological, sexual and obstetric history of the patients and evaluation of the discontinuity in the early detection of Uterine Cervical Cancer (UCC). It was defined as a discontinuity of the gynecological care the woman did not perform the colpocitological examination with the periodicity recommended by the Ministry of Health and/or not return to seek the report. In order to increase the credibility of the tool, a face and content validation was performed with three judges specialized in the area, and application of the form with 332 NBC medical records, verifying their suitability.

\section{Analysis of results and statistics}

In order to achieve the objective of the present study, we investigated associations between the dependent variable:Type of birth control method used (hormonal, barrier, surgical, behavioral 
Social Determinants of Health and their influence on the choice of birth control methods

Ferreira HLOC, Barbosa DFF, Aragão VM, Oliveira TMF, Castro RCMB, Aquino PS, Pinheiro AKB.

or Intrauterine Device (IUD)) and independent variables selected according to SDH Model (SDHM) of Dahlgren and Whitehead (2007) ${ }^{(5)}$, being arranged in four layers, namely: 1) age, family history and menarche; 2 ) onset of sexual activity, personal history, number of partners, gestations and miscarriage; 3 ) marital status, number of children, if the person lives near the unit and adequate gynecological care; 4) schooling and if the person works.

It should be noted that the form considered SDHM Layers 1, 2, 3 and 4, while layer 5 was used in the discussion of the findings, since it refers to the distal or macrodeterminant determinants, involving the economic, cultural and environmental conditions of the society, the current policies, the supranational determinants and the globalization, not being directly related to the personal characteristics of the participants of the study.

The data were processed in the Statistical Package for the Social Sciences (SPSS), version 22.0. Associations were verified by Pearson's Chi-square test, considering a statistical significance when $p<0.05$. Stepwise regression analysis (stepwise or stepwise model) was used to determine which variables could be considered as predictors for choosing the birth control method, that is, to evaluate the strength of the association between them. With regard to stepwise regression analysis, when the regression coefficient $B$ is greater than zero, a positive relationship between the predictor and the result can be affirmed, whereas a coefficient less than zero represent a negative relationship.

\section{RESULTS}

Table 1 presents the characterization of women according to Layers 1, 2, 3 and 4 of SDHM.

The mean age of the women was 30.98 years $( \pm 9.684)$. The age group stood out from the age of $20(86.3 \%)$. The average menarche of these women was 12.96 years ( \pm 1.654$)$. On the family history of gynecological cancer, the most present among the participants was Uterine Cancer (5.2\%), followed by Breast Cancer (4.6\%). Most of them started their sexual activity with more than 15 years (64.6\%), with an average of 17.91 years $( \pm 3,534)$. Approximately half of the participants $(48.2 \%)$ had a sexual partner in life, with a mean of $1.69( \pm 0.745)$. The majority of the participants did not live with their partners during the study (50.2\%), lived near the work (57.7\%), had nine or less years of schooling (59.0\%), (78.6\%), had an average of 2.16 children $( \pm 1.872)$, had never had a miscarriage $(72.5 \%)$ and had discontinuity of gynecological care (87.8\%). About the personal history, the most prevalent among the studied population was the harmful use of alcohol (13.8\%), followed by Sexually Transmitted Infections (STI) (12.4\%), smoking (9.7\%) and hypertension 7.3\%).
Table 1 - Characterization of women with childbearing age according to Layers 1, 2,3 and 4 of the Model of Social Determinants of Health (SDHM), Fortaleza, Ceará, Brazil, 2016

\begin{tabular}{|c|c|c|}
\hline SDHM Layers & n (\%) & $\begin{array}{c}\text { Mean } \pm \text { Standard } \\
\text { Deviation (SD) }\end{array}$ \\
\hline \multicolumn{3}{|l|}{ 1. Individual determinants } \\
\hline Age group (years) $(n=2410)$ & & $30.98 \pm 9.684$ \\
\hline Up to 19 years & $329(13.7)$ & \\
\hline 20 years or above & $2081(86.3)$ & \\
\hline Menarche $(n=2364)$ & & $12.96 \pm 1.654$ \\
\hline Up to 12 years & $994(42.0)$ & \\
\hline 13 years or above & $1370(58.0)$ & \\
\hline \multicolumn{3}{|l|}{ Family history $(n=2410)$} \\
\hline Breast Cancer & $111(4.6)$ & \\
\hline Uterine Cancer & $125(5.2)$ & \\
\hline Ovarian Cancer & $10(0.4)$ & \\
\hline Cervix Cancer & $24(1.0)$ & \\
\hline \multicolumn{3}{|l|}{ 2. Proximal determinants } \\
\hline Onset of sexual activity (years) $(n=2335)$ & & $17.21 \pm 3.534$ \\
\hline$\leq 15$ & $826(35.4)$ & \\
\hline$>15$ & $1509(64.6)$ & \\
\hline Number of partners through life $(n=2020)$ & & $1.69 \pm 0.745$ \\
\hline 1 & $975(48.2)$ & \\
\hline $2-3$ & $702(34.8)$ & \\
\hline$>3$ & $343(17.0)$ & \\
\hline Pregnancy $(n=2410)$ & $1894(78.6)$ & $2.16 \pm 1.872$ \\
\hline Miscarriage $(n=2410)$ & $663(27.5)$ & $0.39 \pm 0.769$ \\
\hline \multicolumn{3}{|l|}{ Personal history $(\mathrm{n}=2410)$} \\
\hline Cardiac disease & $05(0.2)$ & \\
\hline Diabetes & $36(1.5)$ & \\
\hline Cancer & $15(0.6)$ & \\
\hline Harmful use of alcohol & $333(13.8)$ & \\
\hline Smoking & $233(9.7)$ & \\
\hline Hypertension & $177(7.3)$ & \\
\hline Sexually Transmitted Infections & $298(12.4)$ & \\
\hline \multicolumn{3}{|l|}{ 3. Social networks influence } \\
\hline Lives with the partner $(n=2410)$ & $1199(49.8)$ & \\
\hline Lives near the work $(n=2410)$ & $1390(57.7)$ & \\
\hline Discontinuity of gynecological care $(n=2409)$ & $2117(87.8)$ & \\
\hline \multirow{2}{*}{\multicolumn{3}{|c|}{$\begin{array}{l}\text { 4. Intermediate determinants } \\
\text { Schooling (years) }(n=2104)\end{array}$}} \\
\hline & & \\
\hline$\leq 9$ & $1242(59.0)$ & \\
\hline$>9$ & $862(41.0)$ & \\
\hline Works $(n=170)$ & $55(32.4)$ & \\
\hline
\end{tabular}

Note: MDSS - Modelo de Determinantes Sociais da Saúde.

Table 2 - Distribution of birth control methods used by women of childbearing age, Fortaleza, Ceará, Brazil, 2016

\begin{tabular}{cc}
\hline Birth control methods (N=2410) & $\mathbf{n}(\%)$ \\
\hline Hormonal methods & $602(25.0)$ \\
Barrier methods & $520(21.5)$ \\
Surgical methods & $465(19.3)$ \\
Behavioral methods & $59(2.5)$ \\
Intrauterine Device & $42(1.7)$ \\
Not informed & $722(30.0)$ \\
\hline
\end{tabular}

Table 2 shows the distribution of birth control methods used by women of childbearing age.

Regarding birth control methods, hormonal methods were the most used among the participants (25.0\%). The barrier methods 
were the second most used group (21.5\%), followed by surgical methods (19.3\%). The behavioral methods and the IUD were the least used, with $2.5 \%$ and $1.7 \%$, respectively. This information is underreported in the medical records in $30.0 \%$ of the data.

Table 3 shows the distribution of women's SDH, according to Layers 1, 2, 3 and 4, regarding birth control methods.
In the analysis of the association between birth control methods and SDHM layers, statistical significance was observed in some situations. In the Layer 1, corresponding to the individual determinants, age was considered a direct influence on the choice of birth control methods, presenting statistical significance with the barrier methods $(p<0.001)$, hormonal methods $(p=0.015)$, surgical methods $(p<0.001)$

Table 3 - Distribution of women with childbearing age according to Layers 1, 2, 3 and 4 of the Social Determinants of Health Model (SDHM) with birth control methods, Fortaleza, Ceará, Brazil, 2016

\begin{tabular}{|c|c|c|c|c|c|c|c|c|c|c|}
\hline \multirow[t]{2}{*}{ SDHM Layers } & \multicolumn{2}{|c|}{$\begin{array}{c}\text { Barrier methods } \\
\mathrm{n}(\%)\end{array}$} & \multicolumn{2}{|c|}{$\begin{array}{c}\text { Hormonal methods } \\
\mathrm{n}(\%)\end{array}$} & \multicolumn{2}{|c|}{$\begin{array}{c}\text { Surgical methods } \\
n(\%)\end{array}$} & \multicolumn{2}{|c|}{$\begin{array}{c}\text { Intrauterine Device } \\
\text { n (\%) }\end{array}$} & \multicolumn{2}{|c|}{$\begin{array}{c}\text { Behavioral methods } \\
\mathrm{n}(\%)\end{array}$} \\
\hline & Yes & No & Yes & No & Yes & No & Yes & No & Yes & No \\
\hline \multicolumn{11}{|c|}{ Individual determinants } \\
\hline \multicolumn{11}{|c|}{ Age group (years) $(n=2410)$} \\
\hline Up to 19 years & $106(32.2)$ & $223(67.8)$ & $100(30.4)$ & 229 (69.6) & $03(0.9)$ & $326(99.1)$ & $00(0.0)$ & $329(100.0)$ & $09(2.7)$ & $320(97.3)$ \\
\hline 20 years or above & $414(19.9)$ & $1667(80.1)$ & $502(24.1)$ & $1579(75.9)$ & $462(22.2)$ & $1619(77.8)$ & $42(2.0)$ & $2039(98.0)$ & $50(2.4)$ & $2031(97.6)$ \\
\hline$P$ value & \multicolumn{2}{|c|}{$<0.001$} & \multicolumn{2}{|c|}{0.015} & \multicolumn{2}{|c|}{$<0.001$} & \multicolumn{2}{|c|}{0.009} & \multicolumn{2}{|c|}{0.717} \\
\hline \multicolumn{11}{|l|}{ Menarche $(n=2364)$} \\
\hline Up to 12 years & $209(21.0)$ & $785(79.0)$ & $288(29.0)$ & 706 (71.0) & $168(16.9)$ & $826(83.1)$ & $14(1.4)$ & $980(98.6)$ & $20(2.0)$ & $974(98.0)$ \\
\hline 13 years or above & $305(22.3)$ & $1065(77.7)$ & $306(22.3)$ & $1064(77.7)$ & $289(21.1)$ & $1081(78.9)$ & $27(2.0)$ & $1343(98.0)$ & $39(2.8)$ & $1331(97.2)$ \\
\hline$P$ value & \multicolumn{2}{|c|}{0.472} & \multicolumn{2}{|c|}{$<0.001$} & 0.011 & & \multicolumn{2}{|l|}{0.301} & \multicolumn{2}{|c|}{0.199} \\
\hline \multicolumn{11}{|l|}{ Proximal determinants } \\
\hline \multicolumn{11}{|c|}{$\begin{array}{l}\text { Onset of sexual activity (years) } \\
(\mathrm{n}=2335)\end{array}$} \\
\hline$\leq 15$ & $193(23.4)$ & $633(76.6)$ & $250(30.3)$ & $576(69.7)$ & $133(16.1)$ & $693(83.9)$ & $13(1.6)$ & $813(98.4)$ & $16(1.9)$ & $810(98.1)$ \\
\hline$>15$ & 315 (20.9) & $1194(79.1)$ & $332(22.0)$ & $1177(78.0)$ & $312(20.7)$ & $1197(79.3)$ & $28(1.9)$ & $1481(98.1)$ & $42(2.8)$ & $1467(97.2)$ \\
\hline$P$ value & 0.1 & 163 & $<0$ & 001 & 0.007 & & 0.620 & & & 209 \\
\hline Pregnancy $(n=2410$ & & & & & & & & & & \\
\hline Yes & $364(19.2)$ & $1530(80.8)$ & $436(23.0)$ & $1458(77.0)$ & $455(24.0)$ & $1439(76.0)$ & $41(2.2)$ & $1853(97.8)$ & $51(2.7)$ & $1843(97.3)$ \\
\hline No & $156(30.2)$ & $360(69.8)$ & $166(32.2)$ & $350(67.8)$ & $10(1.9)$ & $506(98.1)$ & $01(0.2)$ & $515(99.8)$ & $08(1.6)$ & $508(98.4)$ \\
\hline$P$ value & $<0$. & 001 & $<0$ & 001 & $<0.001$ & & 0.002 & & & 37 \\
\hline Miscarriage $(n=241$ & & & & & & & & & & \\
\hline Yes & $129(19.5)$ & $534(80.5)$ & $140(21.1)$ & $523(78.9)$ & $179(27.0)$ & $484(73.0)$ & $14(2.1)$ & $649(97.9)$ & $17(2.6)$ & $646(97.4)$ \\
\hline No & $391(22.4)$ & $1356(77.6)$ & $462(26.4)$ & $1285(73.6)$ & $286(16.4)$ & $1461(83.6)$ & $28(1.6)$ & $1719(98.4)$ & $42(2.4)$ & 1705 (97.6) \\
\hline$P$ value & 0.1 & 119 & 0.0 & 007 & $<0.001$ & & 0.394 & & & 320 \\
\hline Personal history & & & & & & & & & & \\
\hline Smoking $(\mathrm{n}=2408)$ & & & & & & & & & & \\
\hline Yes & $44(18.9)$ & $189(81.1)$ & $45(19.3)$ & $188(80.7)$ & $59(25.3)$ & $174(74.7)$ & $07(3.0)$ & $226(97.0)$ & $06(2.6)$ & $227(97.4)$ \\
\hline No & $475(21.8)$ & $1700(78.2)$ & $557(25.6)$ & $1618(74.4)$ & $406(18.7)$ & $1769(81.8)$ & $34(1.6)$ & 2141 (98.4) & $53(2.4)$ & 2122 (97.6) \\
\hline$P$ value & 0.2 & 297 & 0.0 & 335 & 0.014 & & 0.106 & & & 397 \\
\hline Hypertension $(n=24$ & & & & & & & & & & \\
\hline Yes & $38(21.5)$ & $139(78.5)$ & $26(14.7)$ & $151(85.3)$ & $66(37.3)$ & $111(62.7)$ & $03(1.7)$ & $174(98.3)$ & $03(1.7)$ & $174(98.3)$ \\
\hline No & $482(21.6)$ & $1750(78.4)$ & $576(25.8)$ & $1656(74.2)$ & 399 (17.9) & $1833(82.1)$ & $39(1.7)$ & $2193(98.3)$ & $56(2.5)$ & $2176(97.5)$ \\
\hline$P$ value & 0.9 & 969 & 0.0 & 001 & $<0.001$ & & 0.959 & & & 500 \\
\hline Social networks influe & & & & & & & & & & \\
\hline $\begin{array}{l}\text { Lives with the partn } \\
(\mathrm{n}=2410)\end{array}$ & & & & & & & & & & \\
\hline Yes & $223(18.6)$ & $976(81.4)$ & $288(24.0)$ & $911(76.0)$ & $305(25.4)$ & $894(74.6)$ & $27(2.3)$ & $1172(97.7)$ & $38(3.2)$ & 1161 (96.8) \\
\hline No & $297(24.5)$ & $914(75.5)$ & $314(25.9)$ & $897(74.1)$ & $160(13.2)$ & $1051(86.8)$ & $15(1.2)$ & $1196(98.8)$ & $21(1.7)$ & $1190(98.3)$ \\
\hline$P$ value & $<0$ & 001 & 0.2 & 279 & $<0.001$ & & 0.057 & & & 23 \\
\hline $\begin{array}{l}\text { Discontinuity of } \\
\text { gynecological care ( } r\end{array}$ & & & & & & & & & & \\
\hline Yes & $445(21.0)$ & $1672(79.0)$ & $502(23.7)$ & $1615(76.3)$ & $411(19.4)$ & $1706(80.6)$ & $37(1.7)$ & $2080(98.3)$ & $48(2.3)$ & $2069(97.7)$ \\
\hline No & $75(25.7)$ & $217(74.3)$ & $99(33.9)$ & $193(66.1)$ & $54(18.5)$ & $238(81.5)$ & $05(1.7)$ & $287(98.3)$ & $11(3.8)$ & $281(96.2)$ \\
\hline$P$ value & 0.0 & 699 & $<0$. & 001 & 0.709 & & 0.965 & & & 20 \\
\hline Intermediate determi & & & & & & & & & & \\
\hline Schooling (years) ( $n=$ & & & & & & & & & & \\
\hline$\leq 9$ & $244(19.6)$ & $998(80.4)$ & $278(22.4)$ & 964 (77.6) & $298(24.0)$ & $944(76.0)$ & $20(1.6)$ & $1222(98.4)$ & $31(2.5)$ & $1211(97.5)$ \\
\hline$>9$ & $208(24.1)$ & $654(75.9)$ & $239(27.7)$ & $623(72.3)$ & $108(12.5)$ & 754 (87.5) & $15(1.7)$ & $847(98.3)$ & $27(3.1)$ & 835 (96.9) \\
\hline$P$ value & 0.0 & 14 & 0.0 & 005 & $<0.001$ & & 0.819 & & & 81 \\
\hline
\end{tabular}


and the IUD ( $p=0.009)$. That is, depending on the age group, these methods can be more or less used. The majority of women who had precocious menarche, less than 12 years old (71.0\%), did not use hormonal methods $(p<0.001)$ or surgical $(p=0.011)$.

When analyzing Layer 2, referring to the proximal determinants, one can observe an association of the onset of sexual activity with the choice of methods. Most women who started sexual activity 15 years of age or younger did not use hormonal methods $(p<0.001)$ or surgical $(p=0.007)$. Regarding pregnancy, the highest rates of women who were pregnant were associated with non-use of barrier methods ( $p<0.001)$, of the hormonal methods $(p<0.001)$, surgical $(p<0.001)$ and IUD ( $p=0.002)$. Of those who had undergone some miscarriage, $78.9 \%$ did not use hormonal methods $(p=0.007)$ and $73.0 \%$ did not use surgical methods ( $p<0.001$ ).

Regarding personal history, still located on the layer of proximal determinants according to the SDHM, smoking was significantly associated with the choice of method. Approximately $80 \%$ of women who smoked did not use hormonal methods $(p=0.035)$ and $74.7 \%$ of them did not use surgical methods ( $p=0.014)$. Of the participants with a history of hypertension, $85.3 \%$ did not use hormonal methods ( $p=0.001$ ) and $62.7 \%$ did not use surgical methods ( $p<0.001)$.

Layer 3 groups social networks influence. The fact of living with the partner was associated with the choice of methods. Most of the women (96.8\%) who lived with the partner did not use behavioral methods ( $p=0.023$ ), $81.4 \%$ did not use barrier methods ( $p<0.001$ ) and 74.6\% 0.001). Regarding gynecological care, $76.3 \%$ of the women with Discontinuity of gynecological care did not use hormonal methods $(p<0.001)$.

By associating the social determinants of Layer 4, or intermediate determinants, with the birth control methods, it was observed significant in relation to schooling. The majority of women with nine years of schooling or less did not use barrier methods $(80.4 \%, \mathrm{p}=$ $0.014)$, hormonal $(77.6 \%, p=0.005)$ or surgical $(76.0 \%, p<0.001)$.

Table 4 shows the results of the stepwise regression analyzes with the prediction variables and the type of birth control method. It is emphasized that only the social determinants that showed a statistically significant association in the bivariate analysis were included in the stepwise regression model.
It was noticed that age was a positive predictor $(B=0.081)$ for the barrier methods, while it was negatively related $(B=-0,121)$ with the surgical methods. Onset of sexual activity was considered a predictor for hormonal methods $(B=0.095)$. The number of pregnancies was negatively correlated with the barrier methods $(B=-0.073)$ and hormonal $(B=-0.079)$, whereas it was considered a positive predictor for the surgical methods $(B=0.120)$ and the Intrauterine Device $(B=0.016)$. The number of miscarriages was considered a predictor of the surgical methods ( $B=0.042$ ). Having presented a personal history of hypertension was a predictor for the hormonal methods $(B=0.085)$ and was negatively related to the surgical methods $(B=-$ $0.160)$. In relation to the marital status, living with the partner was considered a negative predictor for behavioral methods $(B=-0.014)$, while the discontinuity of gynecological care was negatively related to hormonal methods $(B=-0.102)$ and surgical $(B=-0.080)$. Finally, schooling was considered a negative predictor for the hormonal methods $(B=-0.051)$ and positive for the surgical methods $(B=0.077)$.

\section{DISCUSSION}

The individual determinants are based on the model of Dahlgreen and Whithead (2007), with particular characteristics of age, sex and genetic factors that, of course, influence their potential and their health conditions ${ }^{(4-5)}$.

It is observed that, depending on the age group, birth control methods can be more or less used. In the case, the greater the age, the more chance of using barrier methods $(B=0.081)$. There is also a negative relation of the surgical methods $(B=-0,121)$ with the lowest age.

The study found that younger female teenagers and those living in urban areas were those in which a lower prevalence of condom use was identified ${ }^{(7)}$. However, among young people in Brazil, there was a higher prevalence of condom use ${ }^{(8)}$.

Adolescence is found in a particular age group, generally between 12 and 19 years old, and when one analyzes teenagers' perceptions of condom use, it is understood that there is often a dependence of teenagers on the partner's decision, either by opposition him or by being in a serious relationship. There is also the initiative of the teenager herself not to use the barrier method for referring annoyance ${ }^{(9)}$. Therefore, it is fundamental

Table 4 - Stepwise regression between Social Determinants of Health (SDH) and birth control methods, Fortaleza, Ceará, Brazil, 2016

\begin{tabular}{|c|c|c|c|c|c|c|c|c|c|c|c|c|c|c|c|}
\hline \multirow{2}{*}{ Predictor variables } & \multicolumn{3}{|c|}{$\begin{array}{c}\text { Barrier } \\
\text { methods }\end{array}$} & \multicolumn{3}{|c|}{$\begin{array}{l}\text { Hormonal } \\
\text { methods }\end{array}$} & \multicolumn{3}{|c|}{$\begin{array}{l}\text { Surgical } \\
\text { methods }\end{array}$} & \multicolumn{3}{|c|}{$\begin{array}{l}\text { Intrauterine } \\
\text { Device }\end{array}$} & \multicolumn{3}{|c|}{$\begin{array}{c}\text { Behavioral } \\
\text { methods }\end{array}$} \\
\hline & B & SE & $\boldsymbol{\beta}$ & B & SE & $\boldsymbol{\beta}$ & B & SE & $\beta$ & B & SE & $\boldsymbol{\beta}$ & B & SE & $\boldsymbol{\beta}$ \\
\hline \multicolumn{16}{|l|}{ 1- Individual determinants } \\
\hline Age group (years)* & 0.081 & 0.028 & 0.068 & - & - & - & -0.121 & 0.026 & -0.107 & - & - & - & - & - & - \\
\hline \multicolumn{16}{|l|}{ 2- Proximal determinants } \\
\hline Onset of sexual activity (years)* & - & - & - & 0.095 & 0.021 & 0.103 & - & - & - & - & - & - & - & - & - \\
\hline Pregnancy* & -0.073 & 0.024 & -0.072 & -0.079 & 0.26 & -0.074 & 0.120 & 0.024 & 0.123 & 0.016 & 0.007 & 0.049 & - & - & - \\
\hline Miscarriage* $^{*}$ & - & - & - & - & - & - & 0.042 & 0.020 & 0.047 & - & - & - & - & - & - \\
\hline Hypertension* & - & - & - & 0.085 & 0.036 & 0.051 & -0.160 & 0.032 & -0.106 & - & - & - & - & - & - \\
\hline \multicolumn{16}{|l|}{ 3- Social networks influence } \\
\hline Lives with the partner* & - & - & - & - & - & - & - & - & - & - & - & - & -0.014 & 0.006 & -0.046 \\
\hline Discontinuity of gynecological care* & - & - & - & -0.102 & 0.028 & -0.080 & -0.080 & 0.017 & -0.102 & - & - & - & - & - & - \\
\hline \multicolumn{16}{|l|}{ 4- Intermediate determinants } \\
\hline Schooling* & - & - & - & -0.051 & 0.020 & -0.058 & 30.077 & 0.017 & 0.097 & - & - & - & - & - & - \\
\hline
\end{tabular}

Note - *Variables that presented significant correlation - $p<0.05 ; B$ - Partial regression coefficient; SE - Standard error; $\beta$ - Standardized regression coefficient. 
that actions of orientation and prevention are directed to this specific population, both feminine and masculine, because there is a joint responsibility in this aspect.

In the age group between 20 and 29 years, he leaves his adolescence and considers himself young. It is worth emphasizing that this maturity may tend to use barrier methods and other types, such as surgical and IUD. For sterilization, there is greater participation among women aged 25-29 years, $18 \%$ in Colombia and $16 \%$ in Brazil(8).

In this sense, health education is one of the vital components of care, since it guarantees the exercise of sexuality in a full, healthy and responsible way. However, the importance of directing actions according to the age group is emphasized, since there is influence of age in choosing the birth control method.

Proximal determinants represent behavior and individual lifestyles, based on personal choices made by free will and usually conditioned by society or by what is made available by $\mathrm{it}^{(4)}$.

Participants in the study who started sexual activity up to age 15 did not use hormonal methods $(p<0.001)$ or surgical $(p=0.007)$, for the most part. However, the onset of sexual activity was considered a predictor for the hormonal methods $(B=0.095)$.

It is known that the sexual life of most Brazilians begins during adolescence, more precisely between 13 and 15 years of age ${ }^{(10)}$, and many still do not have adequate support and knowledge to choose and use preventive methods against STI and unplanned pregnancy.

From the teenagers who participated in a study to estimate the prevalence of sexual initiation and use of birth control methods, there were increasing prevalence of onset of sexual activity from 12 years of age, reaching $56.4 \%$ among those 17 years old ( $95 \% \mathrm{Cl} 53.9-58.9$ ). The use of the male condom was used by $68.8 \%$ of teenagers. The use of the oral contraceptive pill was much less frequent, $13.4 \%{ }^{(7)}$.

However, there is a higher prevalence of the use of hormonal methods among the young population ${ }^{(8)}$. In a study that analyzed the prevalence of current use of hormonal methods by Brazilian women, it was identified that the use of oral contraceptives predominated in relation to monthly or quarterly injectables and both were more prevalent in the age group between 20 and 29 years $(49.5 \%, 95 \% \mathrm{Cl} 46.9-52.0)^{(11)}$.

These data may reflect insufficient information about available birth control methods and their adequate use due to low teenager adherence to reproductive planning. Often, through inexperience coupled with misinformation, they tend to choose the most accessible and widespread method in society, the condom. However, as they become sexually active youngsters, other factors arise that interfere with this choice, making them opt for alternatives such as hormonal methods.

There was also a negative relation between the number of pregnancies with barrier methods $(B=-0.073)$ and hormonal $(B=-$ 0.079). On the other hand, the higher the number of pregnancies, the higher the probability of using the surgical method $(B=0.120)$ and the IUD $(B=0.016)$.

In Brazil and Colombia, oral and injectable hormones and condoms are the most commonly used by women with fewer children. What is also observed is that the surgical methods, such as tubal ligation and vasectomy, increase as the number of children increases, presenting a significant prevalence. This was expected, since more children may indicate that the couple has reached the desired number or, in some cases, experienced the experience of an unplanned pregnancy, encouraging the search for more effective methods ${ }^{(8)}$.

Other determining factors in the choice of method are tuxedo and hypertension. According to data identified in this study, the majority of women who smoked $(p=0.035)$ and had a history of hypertension ( $p=0.001$ ) did not use hormonal methods, however having previous hypertension was positively related to the use of this type of method $(B=0.085)$.

According to the eligibility criteria for choosing birth control methods from the World Health Organization (WHO), for those who present hypertension or are smokers, in general, the use of combined hormonal methods is not recommended, as there is presence of ethinyl estradiol, hormone which induces significant changes in the coagulation system and acts directly on the vascular wall, and may be favorable for the development of thromboembolic events, such as Stroke ${ }^{(12)}$.

This study investigated the influence of the use of hormonal contraceptives on the occurrence of Stroke, and found that smokers who used combined oral contraceptives presented 8.57 more chances and a greater relative risk (4.9) of Stroke when compared to the chance of non-smokers (3.1) or the relative risk of those who have never used this type of method (4.2) $)^{(13)}$.

For this reason, professionals trained to identify risk factors, guide and perform appropriate behavior are important in the context of reproductive planning in order to avoid possible complications.

Layer 3 highlights the influence of community and support networks, whose level of social cohesion is relevant to the health of the population ${ }^{(4)}$. There was a statistically significant relationship between living with the partner and the choice of birth control methods. It was observed that, even the woman living with the partner, adherence to the barrier methods $(p<0.001)$ and behavioral $(p=0.023 ; B=-0.014$ ) were low. This non-adherence to the barrier method between couples corroborates a study carried out with 1820 teenagers from public schools in the city of Uberaba, MG, in the years 2005 and 2006, in which it was shown that condom use is reported as inconvenient by teenagers. $(p=0.001)$. The main reasons were "discomfort/nuisance" for both sexes $(p<0.001)$ and "interference in pleasure/lust" for boys $(p<0.001)^{(14)}$.

It should be emphasized that relationships with established partners were also identified as factors for non-use of the condom, which may be related to overconfidence, inability to negotiate between partners due to communication difficulties, fear of the partner's attitude/thinking or submission to the male partners wills, in the case of women ${ }^{(14-15)}$.

It is essential to prioritize the dialogue between the couple and access to information about the benefits of the method, providing freedom of expression and the possibility of including condoms in sexual relations.

The difficulty of using behavioral methods is also present, since the feeling of fear and insecurity in performing this type of method usually occurs because it is a practice that requires women to know their fertility pattern so that there is no failure in the desired goals ${ }^{(16)}$.

For this, it is important the support of a health professional to orient properly about the correct technique of the method, 
besides self-knowledge, autonomy and emancipation of the woman and the participation of the partner in this process.

When referring to living near the health service, in the present study there was no significant relation with the choice of the type of birth control method, but it is admitted that the young people in the urban centers have greater access to health services and information, favoring the choice and use of the method ${ }^{(3)}$. It is worth emphasizing that the health service should not only facilitate access, but also provide adequate reproductive health education so that the couple has security in their choices.

Referring to gynecological care and the use of birth control method, it was found that the majority of women who discontinued this care used less hormonal methods $(p<0.001 ; B=-0.102)$ and surgical $(B=-0.080)$.

This discontinuity can be justified by the fear and/or shame of going to the public services that distribute the birth control methods, among them the hormonal ones, making it difficult to access them, and by the lack of professional orientation to perform a surgical method. Other aspects that can also interfere are the insufficiency of money to acquire the method, beliefs about its side effects, misinformation about its correct use, bureaucracy in the case of the surgical method, and not liking the method itself $\mathrm{f}^{(17)}$.

Representing intermediate determinants are factors related to living and working conditions, food availability and access to essential environments and services, such as health and education, indicating that the social factor can generate differences between individuals ${ }^{(4)}$.

It was verified that schooling was a determining factor for the choice of barrier methods ( $p=0.014)$, hormonal $(p=0.005, B=-0.051)$ and surgical ( $p<0.001, B=0.077)$. Women who presented lower level of schooling, that is, up to nine years of study, tended not to use barrier methods and hormonal. The surgical method was more used by women with higher schooling.

According to an integrative review carried out from August 2012 to January 2013 to identify the factors that interfere with the birth control method in publications of the last ten years, it was evidenced that low schooling was one of the factors that contributed to the adherence to birth control methods, since women with a few years of regular study were not able to assimilate the information passed by the health professional due to the low level of education ${ }^{(3)}$.

Thus, low levels of schooling can influence the achievement of preventive health actions, making women more vulnerable.
Thus, it is clear that access to school can help in a better and better knowledge about birth control methods.

\section{Study limitations}

As a limitation of the study, the underreporting of information in the patients' records can be cited, reflecting data collection and, consequently, reducing the sample number.

\section{Contributions to the sector of Nursing, Health or Public Health}

This study brings a contribution in the area of Public Health, when looking to identify Social Determinants of Health related to the choice of contraceptive methods. Gynecological appointment, as well as reproductive planning, is an important moment for this approach, since other conditions that influence this choice, such as gynecological history and complaints, as well as sexual practice can be identified. Thus, the nurse as an educator starts to take an active role in this identification and orientation process.

\section{CONCLUSION}

The use of SDHM as a tool to evaluate the assistance to women in reproductive planning allowed identifying the direct influence of these determinants on the choice of birth control methods. Through this analysis, it is understood that the simple provision of the method in the health services is not sufficient for reproductive planning to be implemented safely and effectively in the female population.

Studies of this nature are pertinent to understand the context in which the female population is inserted, thus enabling more effective interventions. Statistical associations regarding age, menarche, early sexual activity, pregnancy, miscarriage, smoking, hypertension, marital status, gynecological care and schooling were observed, confirming the importance of the Social Determinants of Health, since they interfere in the way women choose contraceptive methods and the risks that this choice may pose to their health.

In order to improve the health conditions of a population, profound changes in economic patterns and intensification of social policies are necessary. Thus, it is extremely relevant to conduct studies on conditioning factors and Social Determinants of Health so that the actions have a favorable impact on the quality of life of the population.

\section{REFERENCES}

1. Ministério da Saúde (BR). Secretaria de Atenção à Saúde. Departamento de Atenção Básica. Saúde sexual e saúde reprodutiva [Internet]. Brasília: Ministério da Saúde; 2010 [cited 2017 Mar 08]. Available from: http://189.28.128.100/dab/docs/publicacoes/cadernos_ab/abcad26.pdf

2. Ministério da Saúde (BR). Centro Brasileiro de Análise e Planejamento. Pesquisa Nacional de Demografia e Saúde da Criança e da Mulher - PNDS 2006: dimensões do processo reprodutivo e da saúde da criança [Internet]. Brasília: Ministério da Saúde; 2009 [cited 2017 Mar 08]. Available from: http://bvsms.saude.gov.br/bvs/publicacoes/pnds_crianca_mulher.pdf

3. Santos AAP, Ferreira CCF, Silva ML. Factors that interfere in the choice of contraceptive method by the couple: an integrative review. Rev APS [Internet]. 2015 [cited 2017 Mar 08];18(3):368-77. Available from: https://aps.ufjf.emnuvens.com.br/aps/article/view/2516/900

4. Buss PM, Pellegrini FA. Health and its social determinants. Physis [Internet]. 2007 [cited 2017 Mar 09];17(1):77-93. Available from: http:// www.scielo.br/pdf/physis/v17n1/v17n1a06.pdf 
5. Dahlgren G, Whitehead M. Policies and strategies to promote social equity in health. Background document to WHO - Strategy paper for Europe. Stockolm: Arbetsrapport/ Institutet for Framtidsstudier [Internet]. 2007 [cited 2017 Mar 07];14:01-69. Available from: http://www. iffs.se/media/1326/20080109110739filmZ8UVQv2wQFShMRF6cuT.pdf

6. Ministério da Saúde (BR). Conselho Nacional de Saúde. Comissão Nacional de Ética em Saúde. Resolução CNS n 466/12. Normas para pesquisa envolvendo seres humanos [Internet]. Diário Oficial da União, Poder Executivo, Brasília, DF; 2012 [cited 2017 Mar 08]. Available from: http://conselho.saude.gov.br/resolucoes/2012/Reso466.pdf

7. Borges ALV, Fujimori E, Kuschnir MCC, Chofakian CBN, Moraes AJP, Azevedo GD, et al. ERICA: sexual initiation and contraception in Brazilian adolescents. Rev Saúde Pública [Internet]. 2016 [cited 2017 Apr 09];50(suppl 1):15s. Available from: http://www.scielo.br/pdf/rsp/ v50s1/0034-8910-rsp-S01518-87872016050006686.pdf

8. Amorim F, Cavenaghi S, Alves J. Mudanças recentes no uso de métodos contraceptivos no Brasil e na Colômbia: com especial menção à esterilização masculina e feminina. In: Wong LR, (Ed.). Población y salud sexual y reproductiva en América Latina [Internet]. Rio de Janeiro: Asociación Latinoamericana de Población; 2008 [cited 2017 Dec 07]. Available from: http://www.alapop.org/alap/Serielnvestigaciones/ InvestigacionesSI1aSi9/SSR_Partel-4.pdf

9. Silva MRB, Silva LA, Maturana HCA, Silva RB, Santos ME, Figueiredo Filho V. Why they do not use?: a study about the accession of adolescents not contraceptive methods and their Implications. Rev Saúde Redes [Internet]. 2015 [cited 2017 Apr 08];1(4):75-83. Available from: http:// dx.doi.org/10.18310/2446-4813.2015v1n4p75-83

10. Lara LAS, Abdo CHN. [Aspects of early sexual activity]. Rev Bras Ginecol Obstet [Internet]. 2015 [cited 2017 Dec 07];37(5):199-202. Available from: http://www.scielo.br/pdf/rbgo/v37n5/0100-7203-rbgo-37-05-00199.pdf Portuguese

11. Farias MR, Leite SN, Tavares NUL, Oliveira MA, Arrais PSD, Bertoldi AD, et al. Use of and access to oral and injectable contraceptives in Brazil. Rev Saúde Pública [Internet]. 2016 [cited 2017 Oct 25];50(Suppl-2):14s. Available from: http://www.scielo.br/pdf/rsp/v50s2/0034-8910-rsps2-S01518-87872016050006176.pdf

12. World Health Organization-WHO. Medical Eligibility Criteria for Contraceptive Use. 5th ed. [Internet]. World Health Organization; 2015[cited 2017 Oct 25]. Available from: http://apps.who.int/iris/bitstream/10665/181468/1/9789241549158_eng.pdf?ua=1

13. Lima ACS, Martins LCG, Lopes MVO, Araújo TL, Lima FET, Aquino PS, et al . Influence of hormonal contraceptives and the occurrence of stroke: integrative review. Rev Bras Enferm [Internet]. 2017 [cited 2017 Oct 25];70(3):647-55. Available from: http://www.scielo.br/pdf/reben/ v70n3/0034-7167-reben-70-03-0647.pdf

14. Valim EMA, Dias FA, Simon CP, Almeida DV, Rodrigues MLP. Condom use among adolescents in public schools of the city of Uberaba, State of Minas Gerais, Brazil: knowledge and attitudes. Cad Saúde Colet [Internet]. 2015 [cited 2017 Apr 07];23(1):44-9. Available from: http:// www.scielo.br/pdf/cadsc/v23n1/1414-462X-cadsc-23-01-00044.pdf

15. Pires MRM, Balieiro CRB. Representations of heterosexual men on STD/AIDS and condom use in sexual relationships. Saúde Transf Soc [Internet]. 2012 [cited 2017 Apr 07];3(3):89-104. Available from: http://incubadora.periodicos.ufsc.br/index.php/saudeetransformacao/ article/view/1515/2603

16. Magalhães AC, Pereira DSA, Jardim DMB, Caillaux M, Sales VBL. Woman's experience with the choice of the Billings Ovulation Method. Rev Bras Enferm [Internet]. 2013 [cited 2017 Apr 07];66(4):485-92. Available from: http://www.scielo.br/pdf/reben/v66n4/v66n4a04.pdf

17. Patias ND, Dias ACG. First sexual intercourse, information and contraceptive use: a comparison between adolescents. Psicol USF [Internet]. 2014 [cited 2017 Apr 08];19(1):13-22. Available from: http://www.scielo.br/pdf/pusf/v19n1/a03v19n1.pdf 